\title{
Bathing and hygiene Histories from the KITLV Images Archive
}

Jean Gelman Taylor

Studies of cleanliness in social histories of colonialism mirror the concerns of cultural and medical anthropologists in their attention to public health and to comparisons of European and Asian approaches to physical and mental well-being. Daniel Headrick (1981) and Philip Curtin (1989) have demonstrated that colonial rule was both an offshoot of advances in Western science and a sponsor of tropical medicine research. David Arnold (1993), Peter Boomgaard (1996), Lenore Manderson (1996) and the specialists working with Norman Owen (1987) document how 'colonization of the body' proceeded alongside colonization of territory in the late nineteenth and early twentieth centuries in Asia. They study the intrusive, and often resented, impact of Western medical practices such as vaccination, quarantine and autopsy, disinfection of private housing and slum clearance. Autobiographies of prominent Indonesians, such as Margono Djojohadikusumo (1973:17), contain painful memories of being labelled a 'dirty Native' at school by members of the colonial class. And yet the habit of frequent bathing by Indonesians is one of the most characteristic observations made by visitors to Indonesia since the first decades of the Verenigde Oost-Indische Compagnie (VOC, East India Company).

Bathing and cleanliness are the subjects of this chapter. In the first part I draw on studies of evolving Western concepts of cleanliness, developments in house design and household implements, and the visual record of Dutch paintings of the Golden Age. By the mid-nineteenth century, the handkerchief, fork and ceramic washbasin had spread widely amongst Dutch people of all social classes. Dutch people in the Indies brought these items in their travelling kits. Immigrants brought with them habits of personal fastidiousness that such everyday accessories fostered. In the second part of this paper I consider documentation by the Dutch of bathing and 
cleanliness in the Indonesian territories they were colonising from the 1850s. This is the era for which we have a photographic record. The inquiring eye of the camera fixed on Indonesians as well as on Dutch people in the course of their everyday life. My source material comes from the rich store of photographs in the online KITLV Images Archive.

DIRT, WASHING, STATUS AND POLLUTION IN WESTERN EUROPE

It is a commonplace that concern for cleanliness is typically Dutch. Simon Schama brings the weight of academic research to support this received idea in his discussion of seventeenth-century household manuals written for the Dutch housewife. They prescribed daily washing of the entryway to the home, set schedules for cleaning the front room, kitchen and cellar, required daily laundering of clothes, and laid down rules for scouring cooking pans and utensils, for making beds, folding linens, dusting and sweeping. From this evidence Schama argues that cleanliness was associated, in the minds of Dutch people, with pride and shame. A shared understanding of cleanliness fostered a sense of group solidarity. To be clean was to be patriotic, to defend hearth and homeland from dirty, unwanted invaders, whether vermin or aliens (Schama 1987:376-80).

Dutch paintings reinforced this message that dirt and moral failing go together. The ideal home and its occupants are neat and clean; human weakness takes place in scenes of domestic slovenliness. ${ }^{1}$ Schama focuses on the cleaning of objects such as cooking pots and passageways. He has nothing to say of cleaning bodies, but clearly there were rules for personal hygiene too. In Leiden's Doelensteeg a plaque recording establishment in 1650 of an almshouse there for elderly women by the pious Eva van Hoogeveen states that residents were required to bathe themselves at least once each month. Yet, for a country so associated with cleanliness, seemingly few studies have yet been made of the history of personal hygiene in the Netherlands. Academic literature on cleanliness focuses on Italy, France and England. It covers concepts of the body and developments in material culture such as plumbing and the flushing toilet. Historians of ideas explore concepts of pollution and purity;

1 See, for example, 'Interior with two women beside a linen press' by Pieter de Hooch, Rijksmuseum Amsterdam, SK-C-1191 and 'The drunken pair' by Jan Steen, Rijksmuseum, Amsterdam, SK-C-232. 
they argue that dirt and cleanliness are social constructs, or, in Terence McLaughlin's words (1971:1), matters of 'judgement'. Other scholars support investigations of concepts of privacy and sociability through their research into the history of the bath, bathroom and bathing practices. An important factor in all these studies is class, which directs attention to place. Studies focus, accordingly, on palace, drawing room, tavern or street.

Introducing Volume 3 of A history of private life, Philippe Ariès writes that in Europe's Middle Ages many acts of daily life were performed in public in the small confines of village, town and royal court. By contrast, nineteenth-century society was vast and anonymous. Middle class people sought refuge in private, family life; they left the street to the poor. Such social changes were reflected in the planning of grand houses, which now had rooms with designated functions in place of all-purpose spaces. Bedrooms and living rooms were separated from each other and from kitchen and scullery by hallways, front and back staircases (Ariès 1989:1-7).

Schama (1987:380) has observed how frequently the Dutch painted interior views of the households of commoners. He links this painterly trend to growing levels of prosperity in the United Provinces compared with other European states, and to the absence of royalty. In paintings of the living spaces of humbler folk we find the curtained bedstead as a prominent feature, but in paintings of the prosperous bedsteads are replaced by harpsichords and dining tables. Such interiors suggest larger residences and the allocation of personal functions, such as sleeping and lovemaking, to parts of the house to which viewers are not invited. Paintings seem to reflect trends towards privacy and value for the family that Ariès establishes. In many portraits the subject stands at the door or looks out from a window. Doorway and window stop observers at the threshold.

Interior views were being produced throughout the seventeenth century, which is the first century of global operations of the VOC. Dutch merchants hired by the Company were living and working in Asia far from the reach of those emblem books, manuals and paintings that were delivering to Dutch stay-at-homes messages about the proper domicile. The majority of all VOC employees, of course, were soldiers and sailors. Sailors were generally Dutchmen, but soldiers were recruited from the disadvantaged and drifters of Western Europe. For both, street, tavern, hovel and poorhouse were more likely the remembered home than the idealised interiors of instruction manual and painted record.

Historians of the senses tell us that the European body in the seventeenth century was wiped, not washed in water, to cleanse it. 
Lawrence Wright (1960:138) quotes from advice manuals that cautioned against using water on the face, as it would rob the skin of its protective qualities against sun and cold; their authors recommended instead wiping face and hands with a piece of clean linen. Douglas Biow (2006:15) says that soap was first manufactured for washing clothes, not people. McLaughlin's description (1971:42-3) of soap-making and of soap's propensity to rapidly turn rancid explains why this was so. According to Georges Vigarello (1985), people cleaned themselves by washing the undergarments that touched their skin. He and Alain Corbin (1986) document the history of personal linens and changing attitudes to bodily smells. Dutch portraits of the seventeenth century make a show of the spotless linen their middle class subjects wore beneath heavy outer garments of velvet and wool. The white underwear visible at neck and wrists proclaims that the sitters are clean. Dress historians, such as Lou Taylor (2002), emphasize that silks and other expensive cloths were difficult to care for and hence were worn only by people who could afford servants. We can also consider the difficulties of drying clothing in a pre-industrial age and the threat of chills to uncovered bodies in poorly heated rooms.

Concepts of cleanliness are embedded in religious discourse and practice. The mikvah, ${ }^{2}$ baptism and ritual ablution are not mediums for washing away dirt, but for preparing the individual for an altered state, whether recovery of ritual purity, entrance into a relationship with the divine, or readiness for prayers. Water is the element common to Jewish, Christian and Muslim rituals. Uncleanness represents a spiritual condition of sin or ritual impurity. The concept translates into popular wisdom in numerous English expressions: 'Cleanliness is next to godliness'; the ignorant or classes excluded from political power are the 'great unwashed'; cursing and swearing are language of the gutter; a 'filthy' mouth betrays the coarse person.

Biow argues that the topic of cleanliness obliges us to rethink issues such as self-respect, status and social distinction. He says that in Renaissance Italy personal cleanliness became a mark of social honour (Biow 2006:2). The different hygiene habits of others destabilise the viewer's sense of decorum. Such insights help us to understand why it was that travellers to Batavia in the seventeenth century recorded their disgust at the town's Asian inhabitants not only cleaning their entire bodies with water, but doing so in public view in Batavia's canals. Travellers do not speak of the refreshment

2 Mikvah refers to laws of purity in Judaism, to immersion in the ritual bath, and to the bath and bathhouse. 
of bathing in a tropical climate, or of wishing to cool their own bodies. Theirs was a shocked reaction to the transgression of their own understanding of modesty.

Norbert Elias (1994) speaks of the 'advancing shame frontier' in his analysis of European manners. He marks Erasmus's etiquette manual of 1530 for boys as a milestone in this journey into the private, for Erasmus advises his young readers to make acts to do with the body, such as blowing the nose, private, and establishes conventions that restrain spitting and flatulence. Lawrence Wright traces the history of withdrawing personal functions from the public domain in his history of the bathroom and water closet. He begins by reminding us that the bathhouse makes its appearance in societies as a communal place for men. The bathhouses attached to the Greek gymnasium or constructed in Roman and Turkish cities were for sociable relaxation. The public baths and spas of eighteenth and nineteenth-century Europe offered medical cures, and were gathering places for high society to drink the water rather than to clean themselves in it. It is only in the industrial era with its pumps and pipes that the primary function of the bath became cleaning the body. Wright studies interior layouts of houses and the history of manufacturing washbasins, jugs, washstands and cabinets for concealing chamber pots. He discusses the portable hipbath that was used in the kitchen, ${ }^{3}$ and the history of laying underground pipes for bringing water to individual households. He consults sales catalogues. By 1900 the model bathroom in England had a hand basin, bathtub, shower with waterproof curtain and heated towel rail, although most English people were unable to afford houses with a room dedicated to bathing until after World War II (Wright 1960:233, 258).

Personal cleanliness relies on more than tub and flushing toilet. The toothbrush is first mentioned in England in 1651 (Wright 1960:245). European museums display, among their Rococo porcelain collections, toiletry sets with containers for pomades, perfumes and ointments and matching accessories such as brushes, combs and mirrors. Delftware, which was manufactured in Holland as a cheap substitute for expensive porcelain imported from China, offered crockery that was easy to clean and aesthetically pleasing. Cottons imported from India or manufactured in Manchester provided clothing material that was easy to wash and dry. Global trade, forged first by the VOC, brought cotton textiles and china into Dutch households, changing habits and raising the general standard of living.

3 Viriginia Smith (2007:289) records that the mass-produced tin baths date from the 1850s. 
In 1870 the Netherlands Indies was opened to private enterprise and unrestricted immigration from Holland. Suez and steamer encouraged women to travel with their husbands to the Indies. Ideas of the age persuaded Hollanders to think about maintaining a Dutch lifestyle and culture, and to consider their practices as marks of superior civilization. By this time, Dutch men and women were accustomed to eating with knife, spoon and fork, rather than with their fingers; they washed their body on a weekly or daily schedule as a private act, and they were in the practice of changing their clothes regularly. Advice manuals prepared women for the task of maintaining a 'proper' Dutch home in the East. In them the link between personal habits and morality was made explicit. Sections were devoted to hygiene practices for preserving the health and energy of family members in the tropics, the necessity of avoiding certain foods, and other precautions to preserve moral character. Such information was also made available to female emigrants, before their departure from Holland, through the Colonial School for Women and Girls that was established in The Hague in 1920 (Locher-Scholten 1997, 2000). Dutch people who looked down on eating with their fingers and who had codes of privacy regarding bodily functions now took themselves off to the tropics with its fevers and heat.

So what does the KITLV Image Archive reveal? ${ }^{4}$ Examples of paintings and photographs located by the keywords Bathing, Hygiene, Washing, Water, Sanitation, and Rivers yielded many images of Indonesians in the acts of washing their bodies, their clothes or their animals outdoors. Indonesians were also photographed at cisterns for ablutions at mosques, using public toilets along riverbanks and checking their companions' heads for lice.

To find the Indies Dutch in relation to water, I had to use other keywords, such as Swimming and Swimming Pools. Photographs and drawings of the colonial house sometimes showed bathrooms, but not adult Dutch in the act of washing themselves. Mostly the pictorial evidence is of the Dutch at play. A preliminary observation regarding documentation in the KITLV Images Archive is that race and class and absence must be built into our analysis of cleanliness, for there is an abundance of material on Indonesians of the poorer classes and almost nothing on Indonesians of the middle and upper classes or of the Dutch.

4 Images in the KITLV online archive are identified here by their reference number. I refer also to several photographs from private collections published in two of Rob Nieuwenhuys's Tempo doeloe volumes. 
The dominant impression from the images is of life lived outdoors. Early camera technology is partly responsible for this conclusion, for the imperatives of lighting caused photographers to bring their subjects into the garden or street. Adaptation to tropical climate perhaps also produced a greater use of the outdoors for work and leisure. Consequently, those areas of daily life that were invisible in Holland in the late nineteenth century, because they took place in the privacy of the home or workplace, were conducted in public view in the colony and hence visible to the newly arrived immigrant as well as to the photographer. For example, immigrants found, not the closed Dutch house built on to the street, but the colonial bungalow set back in a garden filled with potted plants. Instead of a private domestic life hidden in the cosy interior, Indies home life took place in public view on the front veranda. Photographs of colonial houses show that the Dutch overseas attempted to recreate cosiness in verandas cluttered with round tables, easy chairs, hanging lamps, framed photographs and pot plants. It is as if the veranda is a room with three sides missing.

Everywhere the immigrants came up against evidence of a long history of intermarriage between Dutch men and Indonesian women, of cultural borrowing and adaptation. Indies Dutch ladies, in full view of their indigenous household personnel, walked out on to the back veranda to bathe in a room equipped with a tub of water (4441), or, if their property bordered one of the canals, they went to water's edge to a bathhouse. Eurasian ladies spent the morning hours in kain kebaya ${ }^{5}$ they sat in full view of passers-by or took a morning walk in what seemed, to newcomers, to be their underwear, their long hair unbound and uncovered (Nieuwenhuys 1961:126). It was not only the Indies Dutch who transgressed Dutch boundaries. A huge Indonesian underclass spent their lives in the street, being shaved, having their hair cut or searching for head lice (30456), eating at stalls, washing their bodies and their clothes in canals (53649, 26384), and performing toilet functions (35435). Here were people performing shameful acts without shame in public.

Hygiene practices and class are inextricably linked. For the colony's elites, the proper place for washing the body was behind walls in the bathroom. When Dutch people in the Indies bathed in public, it was for pleasure in the ocean (18014) or the municipal swimming pool (13238). They were fittingly clothed in bathing costumes and removed from the gaze of the masses. Within their leisure complex the only 'Natives' admitted were the swimming pool attendants.

5 A variant of Javanese women's dress consisting of a length of batik wrapped around the waist and falling to the ankles (the kain) and a long-sleeved blouse fastened with ornamental pins or brooches (the kebaya). 


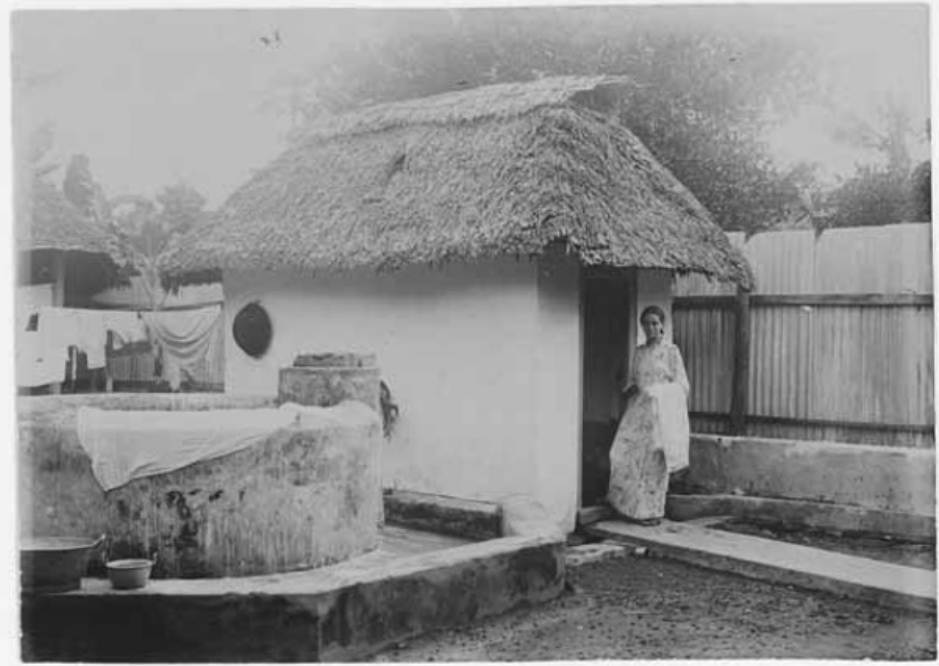

Figure 1. KITLV 4441, Mevrouw Tolk and her bathroom, Ambon, 1914

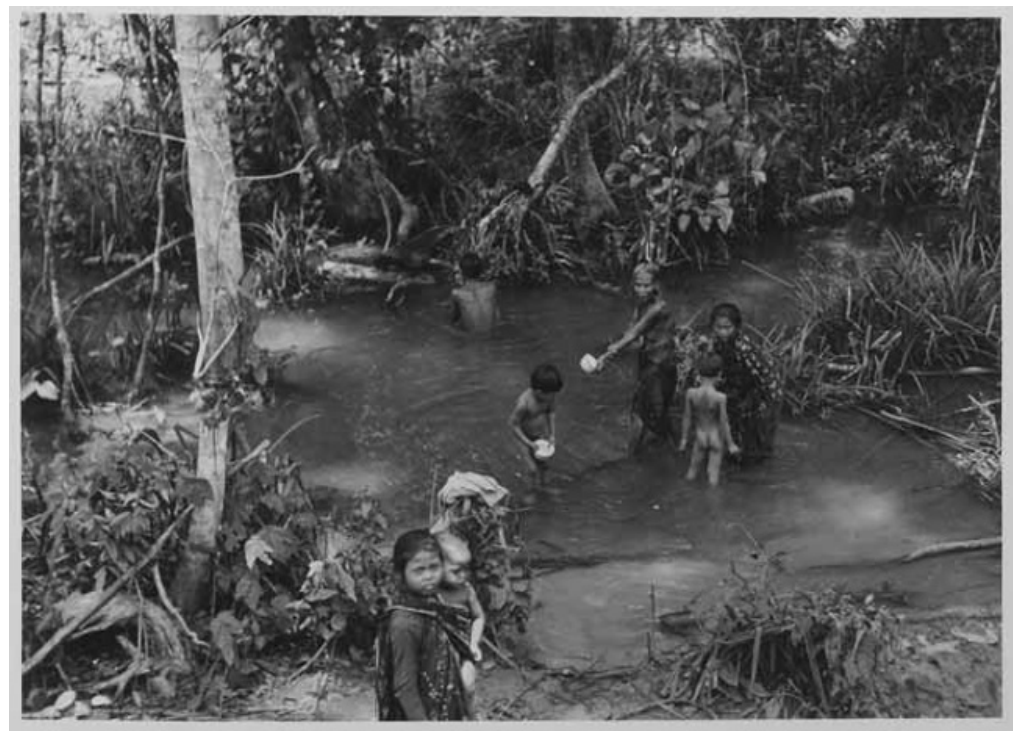

Figure 2. KITLV 53649, Javanese bathing in a stream, Lampung, circa 1940 


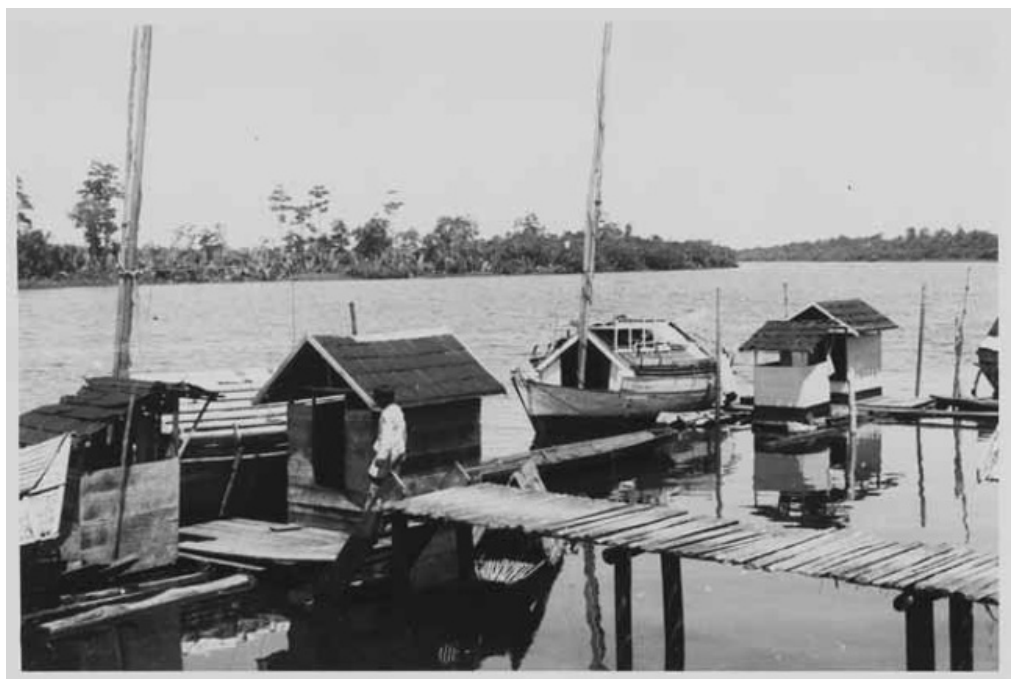

Figure 3. KITLV 35435, Public bathing and toilet facilities for Indonesians, Palembang, circa 1932

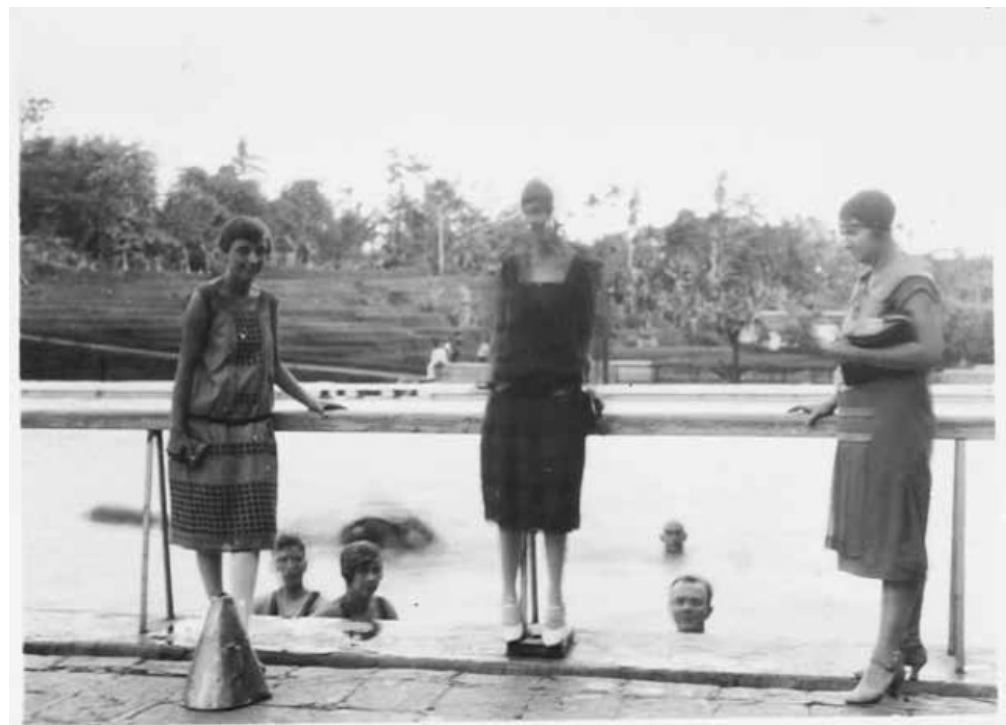

Figure 4. KITLV 13238, Foltynski family at a swimming pool, Bandung, 1925 


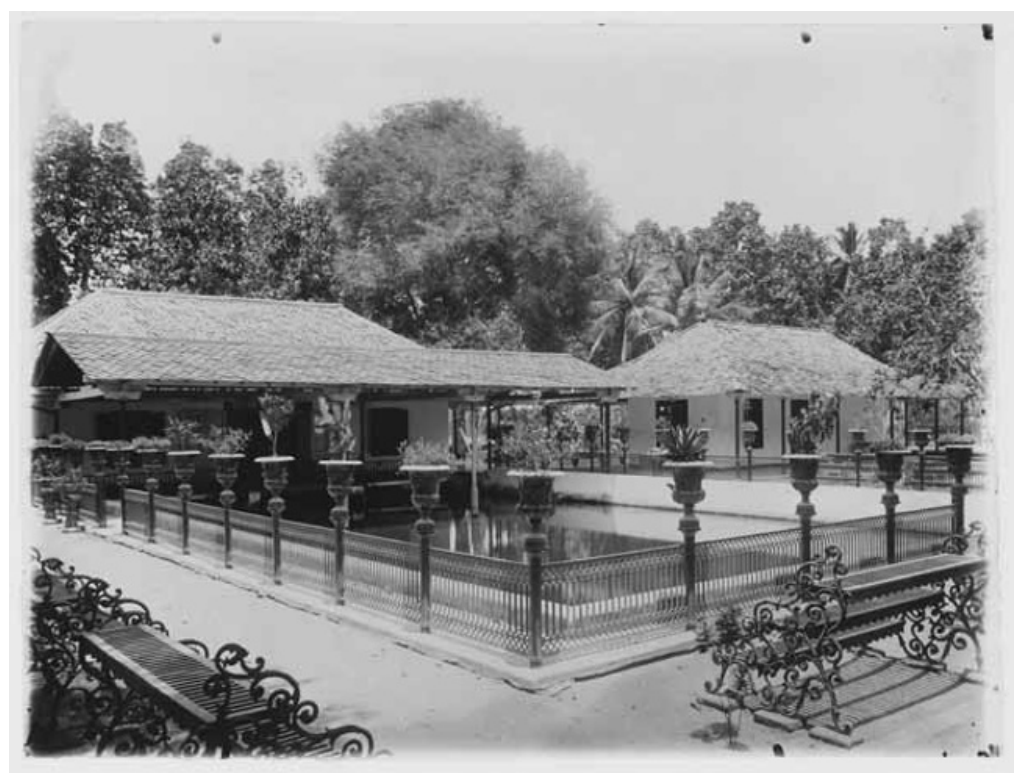

Figure 5. KITLV 4161, Royal bathing place, Ambarwinangun, Yogyakarta, 1895

Historians of bathing and cleanliness learn from the KITLV Images Archive that Java's sultans had bathing places at scenic spots for pleasure. There are photographs of these royal bathing places $(4161,40222)$, but no photographs of sultans relaxing in the water with their wives or with male and female entertainers. ${ }^{6}$ Nor did members of the courts wash themselves in Java's rivers. The aura surrounding Java's sultans discouraged private acts in public view.

Class prerogatives allowed Dutch and Indonesian elites to conceal pastimes and personal hygiene from the public, but their class status prevented them from enjoying their pleasures and maintaining their personal standards of hygiene unaided. Servants and washerwomen, drawn from lower classes that conducted their personal body functions in public, moved freely in the private quarters of bungalow and palace as they maintained the cleanliness of their employers. A favourite subject of the colonial camera was the

6 Anthony Reid (1989), however, draws on accounts of European visitors to Aceh to describe how rulers of the seventeenth-century sultanate enjoyed river bathing and ate feasts while standing in the water. 
faithful Javanese nursemaid carrying her young European charge in a slendang (long scarf) (15285; see also Nieuwenhuys 1982:135). European children apparently did not lose status by being naked and bathed by the Javanese nursemaid. I have found no photographs in the KITLV on-line archive of a Dutch mother washing her own child. In the tropics, that seems to have been the work of servants.

Colonial sensibilities allowed photographers to show Dutch children being washed by Indonesian nursemaids, but I have not found in the KITLV archive contemporary photographs of Indonesian servants washing the children of their royal or aristocratic employers. The Javanese photographer, Kassian Cephas (18451912), apparently did not intrude into the middle class Indonesian home to photograph children being washed by their servants or their mothers. ${ }^{7}$ In his long career, Cephas photographed many of the same subjects as his fellow European professional photographers: Java's antiquities, European and Indonesian dignitaries; colonial infrastructure and commercial enterprises; and colonial 'types'. As photographer to Sultan Hamengkubuwono VII of Yogyakarta, Cephas also took many photographs of the palace, members of the royal family and of palace performers (Knaap 1999), but he apparently did not record on film the private habits of his Javanese employers. Children of sultans and aristocrats are only seen posed stiffly in photographs with parents, never being washed. Clearly, then, there is a history to be written of Indonesian conceptions of public and private, of Indonesian taboos, with attention to class, status and change over time.

The colonial camera had varied roles, from which we can make some preliminary conclusions. There is the camera as historian, preserving a record of bathing sites linked to Java's antiquities. The camera as ethnographer documents royal spas and washing facilities for ritual purification at mosques, and records Indonesians going about their personal hygiene. As tourist, the camera brings us shots of bathing places at scenic spots in the islands. Sometimes, the camera is an obliterator of history. Many snapshots of rivers are emptied of human life: no boats transport goods or ferry people, there are no fishermen, no children at play, no one bathing. As documenter of the ordinary, the camera is of interest to labour historians, for it shows the gendered allocation of jobs. Washing the

7 He did go into the private parts of Indonesian houses, however. Photograph 34594, for example, is of Wahidin Soedirohoesoedoe and acquaintances taken, around 1902, on the back veranda of his house. 
family's clothes appears to be the task of women (26384), but the work in commercial laundries on rivers and canals was performed by men $(26479)$.

The camera is also the creator of rural idylls. Boys wash the family buffalo in the village stream (9721), reminding us of a common theme of painters in the Mooi Indië (Beautiful Indies) school. It is worth noting that the camera, which is a product of modern technology, presents images of Indonesians leading a rural, 'simple' life. Indonesians wash buffalo, but I did not find any photographs of Indonesians washing their employer's motorcar or any other modern object. The camera also contributes to the making of the exotic. The caption to photograph 35201 of Aceh's Gunungan identifies it improbably as the 'bathing place of the sultan's women in the neighbourhood of the sultans' graves near the Kroeëng Daroe at Kotta Goenoengan at Koetaradja'.

The colonial cameraman was ready to record the private acts of others for the Dutch at home in Holland to see. We can think of the camera as voyeur, creating titillating images of naked Balinese women (25964) and naked Balinese men (26154). Other photographs are more coy (40138). The styles are quite different from the wholesome images of Dutch and Eurasian families at the municipal swimming pool and water polo competitions. The only Javanese fully clothed who are posed near water are Javanese swimming pool attendants (55026).

A case can be made that the colonial camera degrades and shames by its intrusion into intensely private acts. In contrast with so much native flesh, the archive contains only a few photographs of adult Europeans washing their bodies or performing toilet functions in public. These Dutch men photographed are German sympathisers. The year is 1940 , the month is May, and the site is a prison camp. Photograph 19063 shows a Dutch man from behind, his buttocks naked. More remarkable still is 19094 of Dutch internees seated on latrines. Taken in similar conditions, a photograph of Dutch women in a Japanese camp (2618) from 1945 following the collapse of Japanese power, draws attention to the misery of their conditions, the primitive washing facilities and the absence of servants. The intent seems to be to convey sympathy for the innocent, wrongfully imprisoned, not to debase them. Traitors, on the other hand, have no honour, self-defence or even a modicum of privacy. They have betrayed the nation, transgressed the boundaries of group solidarity and loyalty. They alone among Europeans deserve to be shown defecating. The camera puts such men below the indigenous majority. 


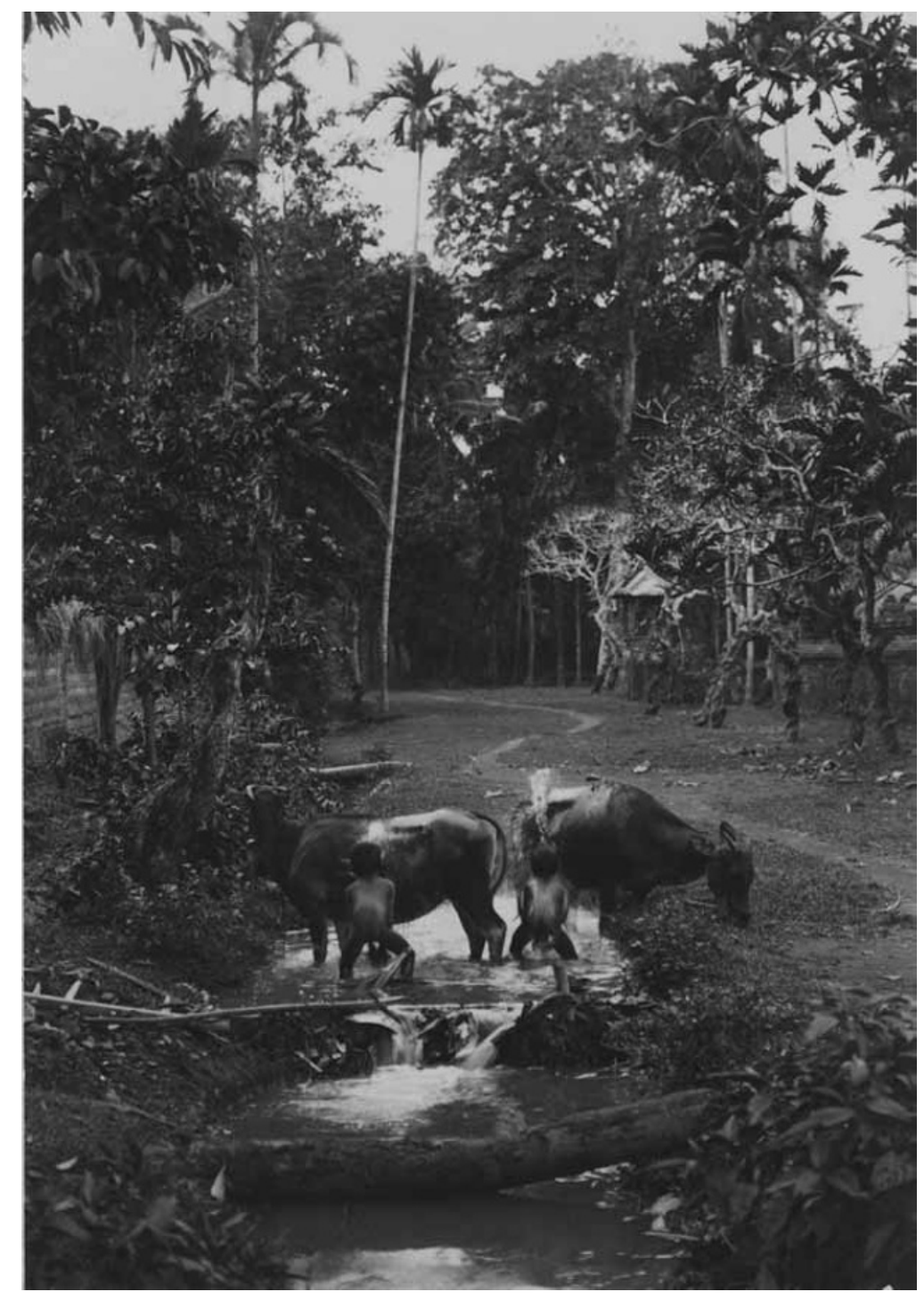

Figure 6. KITLV 9721, Two boys bathing cattle in a river, Bali, circa 1920 


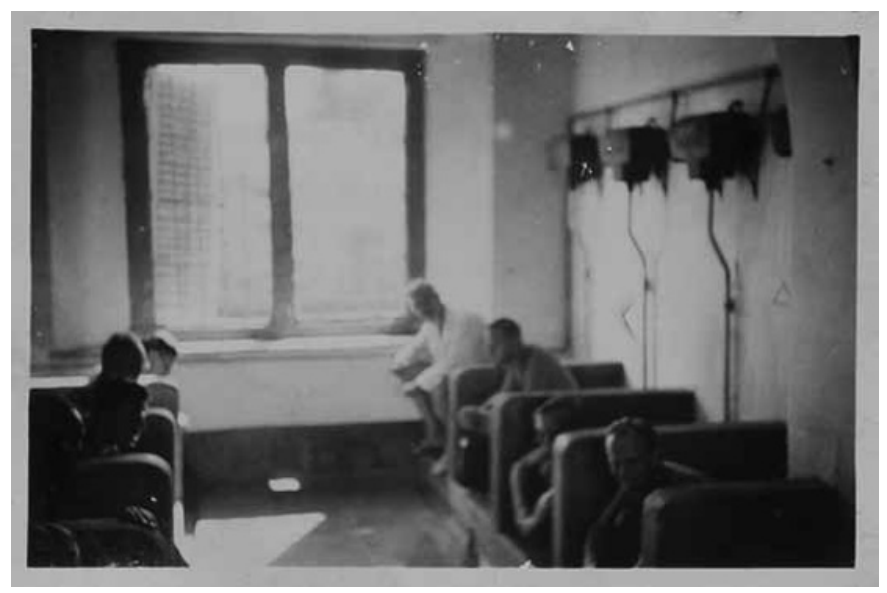

Figure 7. KITLV 19094, European men interned as Nazi sympathizers on latrines, Ngawi, 1940

We can analyse the interest in photographing Asians bathing in terms of the colonial voyeur, following Edward Said (1979), postcolonial and cultural studies, in order to discuss 'Othering' and Western gaze. Or we can be historians. To illustrate this argument we may consider the photographs and paintings in the KITLV online archive of stretches of water that evoke admiration for the beauty of nature in Indonesia. While the colonial camera tells us that rivers functioned as bathroom and laundry for the indigenous majority, in this landscape genre Indonesians do not interrupt or distract the viewer's contemplation of nature. Indonesians are absent altogether or else they are depicted at water's edge in miniature and seen from a great distance (47D-21). We can argue that such river views are contrived to belittle Indonesians, or, as historians, we can note conventions of Dutch landscape painting that depicted people (whether Dutch or Indonesian) fitting humbly and naturally into the physical universe.

TOWARDS INDONESIAN HISTORIES OF BATHING AND HYGIENE

In revisiting this issue of the camera as voyeur or instrument of oppression, we should place Indonesian bathing practices within the history of ideas and technology, as historians have done 
for Europeans and their bathing practices. People bathed and washed their clothes in Batavia's canals, not because they had no shame, but because they lived in houses that lacked bathrooms, laundries and light. Small structures of bamboo and thatch had little space; their windows were of insufficient size to admit the light necessary for many daily activities. Consequently, the majority of Indonesians conducted their everyday activities outdoors. The colony's municipal governments did not install pipes for running water and sewerage systems in most indigenous neighbourhoods. In circumstances where water could not be brought to the house, people had to walk to the water source and carry water back home for drinking and cooking. The kendi (water container) was the ubiquitous item of every household. Made from clay and produced by local potters, it was designed to hold the quantity of water that women could manage to carry (31789). There were no ready means of transporting water in the volumes needed to fill baths. Men could carry at most two water containers suspended from a pole over the shoulders. The abundance of rivers and warm temperatures in Indonesia made bathing outdoors practical, rather than construct public bathhouses that were the solution for cold climates or environments where water was scarce.

The encounter between Dutch and Indonesians occurred at a time when technologies were not comparable. The Dutch had withdrawn most of their personal activities from the street and made them private because they had the engineering technology, the appliances and the funds to enable them to do so. Municipal councils in Holland commissioned sewer systems; water engineers designed them; taxpayers financed the laying of pipes and safe disposal of wastewater; householders paid for the installation of flushing toilets. The Dutch could not have colonised the Indies until advances in Western science and their application through technology made colonies possible. The Dutch who had the water closet were the Dutch who colonised Indonesia. The Dutch who did not have running water and bathrooms, who wiped their face and hands on a piece of linen, were the Dutch of the VOC who lived a precarious existence on the fringes of Indonesian kingdoms. Schama sees dirt as forming a boundary between the Dutch of the seventeenth century and their enemies. Two centuries later the camera's viewpoint could help the Dutch to draw boundaries in foreign lands, preserve an identity, demarcate honour and shame.

Of course, the camera does not record what the photographed thought as they performed their private acts under its gaze. But 
Nieuwenhuys (1961:27) prints a photograph that suggests in the separate groups of men and women in the river an Indigenous etiquette of public bathing. Clearly, the Dutch camera broke the rules of discretion and modesty; perhaps it reinforced for the photographed their sense of being powerless subjects.

In calling for an Indonesian history of cleanliness, we must include a section on the diffusion of Indonesian conceptions and practices to the Dutch. The bathroom, with its tiled water tank and dipper, became a fixture of the Dutch house in the Indies long before Dutch houses in the Netherlands acquired a separate room dedicated to personal bathing. In the Indies the Dutch adapted themselves to the indigenous practice of washing the whole body using this precursor of the shower and they took up the Indonesian habit of regular, daily bathing (36D-722). Newcomers and old-timers alike waxed sentimental about the morning mandi (bathing) and the steaming kopi (coffee) that followed. Here is a major cultural transfer. Europeans adopted Asian personal hygiene habits and values, Asians did not adopt theirs. ${ }^{8}$ The colonized did not give up daily bathing for a wipe or an infrequent wash.

KITLV Images Archive offers material for beginning a history of bathrooms and hygiene in Indonesia. For example, under keywords 'Sanitation' and 'Water' there are numerous photographs of storage tanks, reservoirs and municipal sanitation works; there are also examples of neighbourhood improvement for the Indigenous such as newly built water closets lining the river and municipal street sweepers (30155). No middle class Indonesian washes body or clothes in the river. Middle class people today have a bathroom and they employ servants to wash their clothes. A tee shirt that becomes grubby in the course of the workday is the clothing of Indonesian labourers; the freshly laundered and ironed shirt is the uniform of the office employee. The middle class lady covers her mouth with a handkerchief when laughing; she carries the handkerchief prominently outside of her handbag, establishing status differences from village women who pull on cloth wrapped around the waist to blow their nose and wipe their brow. Nationalists and the Islamic-oriented sometimes prefer using fingers for eating in a now deliberate, conscious show of difference from Western manners and modernity. To European histories of religion and pollution may be added studies of Indonesian practices, such as the use of water transformed by the addition of flower petals for prepar-

8 Smith (2007:235) similarly refers to the influence of baths and showers on Englishmen in eighteenth-century India. 
ing a bride or a corpse. Here water and bathing have the function of marking transitions. There is a history to be written of the rapid transfer of technology, such as bathtubs and flushing toilets in Indonesian hotel bathrooms (37006) and running water in Indonesian kitchens.

Drawing all these threads together, consider a final image. A Dutch man relaxes in a municipal swimming pool; on the wall someone has attached a poster of a man in a bathtub (13119). Water represents cleansing, leisure, status and difference. The KITLV Images Archive is an enormously rich source for social history. It is to be hoped that it may be able to borrow photograph albums in the possession of Indonesian families and make available online more visual documents for further explorations of daily life.

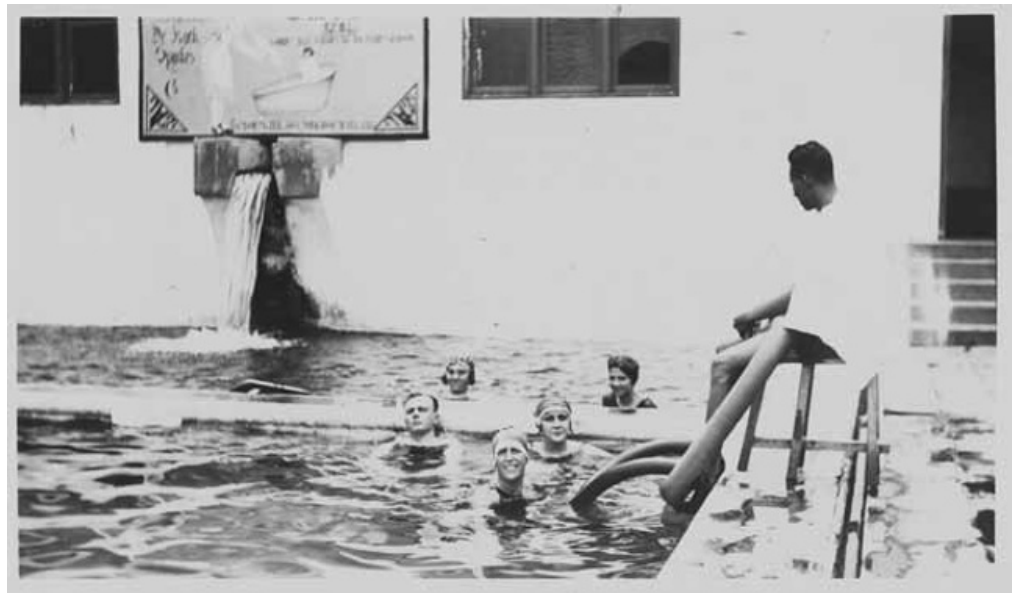

Figure 8. KITLV 13119, Swimming pool and poster, Bandung, 1925 
REFERENCES

Ariès, Philippe

'Introduction', in: Roger Chartier (ed.), A history of private life; Vol. 3: Passions of the Renaissance. Translated by Arthur Goldhammer. Cambridge, MA: Belknap Press of Harvard University Press.

Arnold, David

1993

Colonizing the body; State medicine and epidemic disease in nineteenth-century India. Berkeley, CA: University of California Press.

Biow, Douglas

2006

The culture of cleanliness in Renaissance Italy. Ithaca, NY: Cornell University Press.

Boomgaard, Peter, Rosalia Sciortino and Ines Smyth (eds)

1996

Health care in Java, past and present. Leiden: KITLV Press. [Proceedings 3.]

Corbin, Alain

1986

The foul and the fragrant; Odour and the French social imagination. Oxford: Berg. [Originally published as Le miasme et la jonquille; L'odorat en l'imaginaire social, XVIII'-XIX ${ }^{e}$ siècles. Paris: Aubier Montaigne, 1982.]

Curtin, Philip D.

1989

Death by migration; Europe's encounter with the tropical world in the nineteenth century. Cambridge: Cambridge University Press.

Djojohadikusomo, Margono

1973

Reminiscences from three historical periods. Jakarta: Indira.

Douglas, Mary

2002

Purity and danger; An analysis of concepts of pollution and taboo.

London: Routledge. [Originally published in 1966.]

Elias, Norbert

1994 The civilizing process; The history of manners and state formation and civilization. Oxford: Blackwell. [Originally published as Über den Prozess der Zivilisation; Soziogenetische und psychogenetische Untersuchungen. Basel: Haus zum Falken, 1939.]

Haan, F. de

1923

Oud Batavia; Platenalbum. Batavia: Kolff.

Headrick, D.R.

1981

The tools of empire; Technology and European imperialism in the nineteenth century. New York: Oxford University Press. 
Knaap, Gerrit

1999

Cephas, Yogyakarta; Photography in the service of the sultan. Leiden: KITLV Press.

Locher-Scholten, Elsbeth

1997

'Summer dresses and canned food; European women and Western lifestyles in the Indies, 1900-1942', in: Henk Schulte Nordholt (ed.), Outward appearances; Dressing state and society in Indonesia, pp. 151-80. Leiden: KITLV Press. [Proceedings 4.]

2000

Women and the colonial state; Essays on gender and modernity in the Netherlands Indies, 1900-1942. Amsterdam: Amsterdam University Press.

McLaughlin, Terence

Dirt; A social history as seen through the uses and abuses of dirt. New York: Dorset Press.

Manderson, Lenore

1996

Sickness and the state; Health and illness in colonial Malaya, 1870-1940. Cambridge: Cambridge University Press.

Nieuwenhuys, Rob

1961 Tempo doeloe; Fotografische documenten uit het oude Indie, 18701914. Amsterdam: Querido.

1982 Komen en blijven; Tempo doeloe - een verzonken wereld: Fotografische documenten uit het oude Indië, 1870-1920. Amsterdam: Querido.

Owen, Norman G. (ed.)

1987 Death and disease in Southeast Asia; Explorations in social, medical and demographic history. Singapore: Oxford University Press. [Asian Studies Association of Australia, Southeast Asia Publications Series 14.]

Reid, Anthony

1989 'Elephants and water in the feasting of $17^{\text {th }}$ century Aceh', Journal of the Malaysian Branch of the Royal Asiatic Society 62: 25-44.

Said, Edward W.

1979 Orientalism. New York: Vintage.

Schama, Simon

1987 The embarrassment of riches; An interpretation of Dutch culture in the Golden Age. New York: Knopf.

Smith, Virginia

2007

Clean; A history of personal hygiene and purity. Oxford: Oxford University Press. 
| Jean Gelman Taylor

Taylor, Lou

2002 The study of dress history. Manchester: Manchester University Press.

Vigarello, Georges

1985 Le propre et le sale; L'hygiène du corps depuis le Moyen Age. Paris: Seuil.

Wright, Lawrence

$1960 \quad$ Clean and decent; The fascinating history of the bathroom and the water closet and the sundry habits, fashions and accessories of the toilet principally in Great Britain, France and America. London: Routledge and Kegan Paul. 